\title{
THE APPLICATION OF ISLAMIC BUSINESS ETHICS IN THE CONTEXTS OF PRODUCER AND CONSUMENT: TOWARD CORPORATE SOCIAL RESPONSIBILTY
}

\begin{abstract}
By: Muhammad Anas*
Abstract

In fact, business activities neglecting ethics harm consumers and employees as many cases occurred in this country i.e. formalin case, little wage, oil stealing in Kalimantan, industrial cesspool, transaction of stolen wood, etc. Such facts and cases, to ethical perspective, are due to separation between ethics and business which has a negative impact on human lives. But, ethics and business are two entities being able to be united as one. According to Islam, business is not only an activity to get financial profit, but also the activity to attain essence of humanity as implementation of which becomes human responsibility as creature and caliph in achieving Allah's favor. Therefore, Islam teaches values of business practice such as unity, freedom, responsibility, equality, virtue, and honesty. It is a valuable teaching that all parties such as producer, consumer, employer, employee, and society must apply business ethics, because this does not only deal vertically with producer's responsibility, but also with existence of business activity itself. To put simply, mutual and harmonious relationship among involved parties in business activity will be constructed, if values of business ethics are held as fundamental source for their business practice.
\end{abstract}

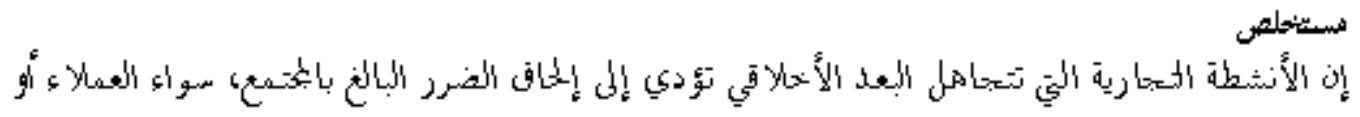

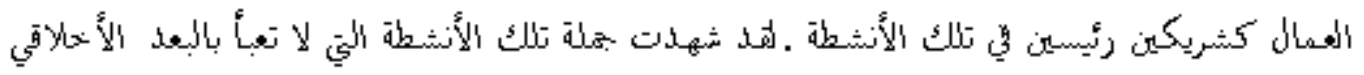

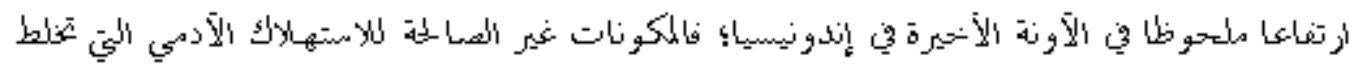

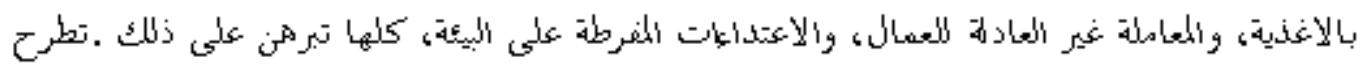

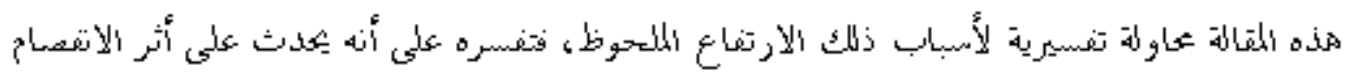

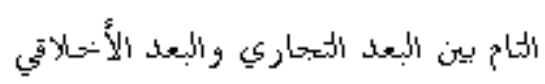

Keyword: ethics, business, human responsibility.

A. Introduction

* Student of Post Graduate Program of UGM Yogyakarta. 
Ethics and social responsibility is still seriously debated by academicians and businessmen. This condition can be understood as that business ethics is applying values of moral standards in policies, institutions, and business activities. They are implemented to increase good willingness in a company or other commercial institutions. This fact leads business ethics to be a part of applied sciences which is linked to business activities in many contexts as well as to provide a set of business values. These values are intended to bridge existing problems in business without ignoring the essence of trade and humanity values.

Business is generally an individual or collective effort which is systematically organized consisting of selling goods and services in order to profit and fulfill social needs ${ }^{1}$, or it can be an institution which produces goods and services demanded by society. $^{2}$ The process of business activities is linked to the relationship between humans and a number of elements of society. From this point, there are two opposing views on the relationship between business and ethics.

For some people, business is defined as an economic activity which is merely aimed at gaining profits. A business activity is intended to profit as big as possible, and, therefore, any ways can be done to get such profits. In this point, principles of morality are deemed as a factor limiting business activities. As a consequence, morality aspects are totally not connected with business activities. Morality dimension in business competition is finally considered as hindering success. Different from this view, the second view argues that business can be united with ethics. This group proposes an argument that ethics is rational reason for all human activities in their life aspects, including business activity. Further traced, the discourse of business ethic appeared as a number of business activities neglect morality.

For businessmen and economists, the idea of business ethics is problematic. The problem is on whether or not morality has a position in business activities and

\footnotetext{
${ }^{1}$ Buchari Alma, Pengantar Bisnis, (Bandung: CV Alfabeta, 1997), p. 16.

${ }^{2}$ Ibid.
} 
economy in general. The term 'moral business myth' is therefore commonly known among them. ${ }^{3}$ Furthermore, Richard T. de George in his Business Ethics argues that moral business myth believes that a businessman cannot go along with morality. Business and morality do not relate each other. It is therefore a mistake that a business activity is measured with morality measurement. ${ }^{4}$ Standing on this position, supporters of this myth do not necessarily leave morality or become immoral. They just behave immorally in terms of being free from performing obligations of explicitly implementing morality in their business activities. ${ }^{5}$

From the perspective of philosophy, borrowing Wittgeinstein's language game, behaviors in a business activity has various principles and rules since a business activity is a form of life or a game which is different from daily activities. Business ethics is an exclusive discourse and does not reflect norms believed by businessmen. The discourse of business is different -in Kuhn's term, incommensurable- from the discourse of business ethics.

Aside of that, some business activities tend to neglect morality. In their opinion, competition in business is competition over capital. With big capital, a businessman may enlarge his/her business coverage which threatens the existence of small entrepreneurs. Monopoly, hoarding, smuggling, and deception exacerbate such condition. Industrialists of big companies often neglect social responsibility which is obliged for them to perform. The relation between employer and employees is constructed on the capitalism system which tends not to pay employees salary properly. It can be seen from the small amount of salary employees received. Workers also often face varied immorally unethical treats.

${ }^{3}$ Ricard T De George, Business Ethics, (New Jersey Hall: Englewood Cliffs, 1986), pp. 5-6. One should distinguish between amoral business myth and immoral business myth. In the former, the parties involved are considered not able to be judged morally, at least neutral, in terms of not negative or not positive. In the latter, business behaviors can morally be judged, though the result, even a priory, is always negative.

${ }^{4}$ Sony Keraf, "Bisakah Bisnis Berjalan tanpa Moralitas", in Basis No. 05-06 (May-June 1997), p. 49.

${ }^{5}$ Alois A Nugroho, "Lima Pandangan Tentang Relevansi Etika Bagi Dunia Bisnis: Sebuah Usaha Pemetaan Awal", in Driyarkara, XXIII no. 3, 1997, pp. 4-5. 
In terms of the relationship between producer and consumers, companies and other businessmen, or a company and its surroundings, morality is also ignored. The principle of gaining big financial profit, producers tend to neglect ethics and harmonious values in this cosmos. In this point, consumers, small and mid entrepreneurs are frequently harmed. This relationship exists in the unhealthy competitive atmosphere. ${ }^{6}$

Moreover, practices of collusion, corruption and nepotism play significant roles in this process. Monetary crisis in Indonesia for instance cannot be separated from such relationship, which is the decline and lack of morality in business activity. This condition leads people to conclude that business is a 'black world'.

More specifically, in the context of industry, the application of business ethics is faced by a number of problem including process, people, and technology. At the process level, classical problems such as cash flow, personal network, quality, competition, and endurance occur. At the people level, the quality of human resources, motivation of entrepreneurs, and the desire to success represent the problem of business ethics. At the technological level, business ethics is faced with the rapid development of technology ${ }^{7}$ which requires speed and efficiency in the work system to attain big financial profit.

In this condition, businessmen who expect for the existence and the sustainability of their company have two choices. First of all, if they apply the principles of business ethics, their business activities will decline. Secondly, on the contrary, if such principles are not implemented, their companies will profit. To look at the relevance and the implementation of business ethics in the business world, three major points are presented in this article: the relation between producer and

\footnotetext{
${ }^{6}$ Aan Dani Saliswijaya, Himpunan Peraturan tentang Class Adion, Jakarta: Gramedia Pustaka Utama, 2004), p. 89.

${ }^{7}$ Hari Sudarmadji, "Masalah-masalah Etika Bisnis", paper of the seminar on Kajian Kritis Strategi Pemulihan Ekonomi Indonesia, in the $45^{\text {th }}$ anniversary of FE UGM, 15 September 2000.
} 
consumer which includes product quality and price and promotion; corporate social responsibilities; and building social responsibilities in the business world.

In this regard, Islamic business ethics is explored as Islam is a religion teaching moral principles which are directly or indirectly connected with business (tijarah). In this discourse, morality rooted from Islamic doctrines gives a big contribution since principles of business ethics takes special place in Islam. Islam provides integrated perspectives on all aspects of life, including social, culture, economy, civil, and politic. Islam also gives guidance for all aspects, including spiritual system and business ethics, economy, and trade politic. ${ }^{8}$

The discussion of Islamic business ethics will address the question of what kind of morality feasible to be applied? The discussion will also serve as the middle ground between universalism and relativism. Islamic business ethics is looked as an ethical subject to meet social needs. Thus, there is no reason for neglecting business ethics as it comes for a certain religion, Islam for instance.

\section{B. The ethical Relation between Producer and Consumer}

Production or manufacturing is a process performed by a producer as an obligatory functional activity. The function of producer is producing goods or services which are aimed at forming added value. Economically, production activities consist of: what product is made, when it is made, what it is made for, how it is produced, how many it is produced. ${ }^{9}$ Consumers take fundamental position in the modern business. Business will have no meaning without consumers. ${ }^{10}$ Slogan 'the customer is king' is not merely intended to attract consumers' interest, but does express the main task of producers to satisfy consumers.

\footnotetext{
${ }^{8}$ Nidal S Sabri dan M. Hisyam Jabir, "Etika Bisnis dan Akutansi", in Sofyan Syafri Harahap, Akuntans Idam (Jakarta: Bumi Aksara, 1997), p. 230.

${ }^{9}$ Muslich, Etika Bisnis Pendkatan Subtantif dan Fungianal, (Yogyakarta: Ekonomia Kampus Fakultas Ekonomi UII Y ogyakarta, 1998), p. 49.

${ }^{10}$ K. Bertens, PengantarEtikaBisnis, (Y ogyakarta: Kanisius, 2000), p. 227.
} 
However, a commodity produced should be relied upon social humanity consideration, even socio-cultural, that is beside it is needed, it must have positive implication. ${ }^{11}$ Besides that, producers also have the obligation to sell safe products for consumers. They must take responsibility if a product has bad low quality and harms the consumers. ${ }^{12}$

This point suggests the importance of balanced relation between producers and consumers. The process of production which efforts to empower and develop its products must be undertaken in the term of public benefits. ${ }^{13}$ The relation between producer and consumer is not unequal one where the former has the right to gain financial profit as big as possible. On the contrary, the relation between he two should be built on the principle of balance in terms of avoiding from centralizing the economic and business power in the hand of the producer.

Islam does not definitely permit activities and practices hoarding economic resources for the certain community's power. ${ }^{14}$ Al-Qardhawi emphasizes that Islam teaches free market system with, at the same time, does not tolerate monopoly, hoarding, smuggling, deception, and manipulation. Nevertheless, Islam permits government to control goods' price in order to fill needs of society as well as to restrain greed practices. ${ }^{15}$

Formally, the relation between producer and consumer is not a contractual relation, that is the right of a party as the consequence of having agreement with the other one. ${ }^{16}$ Instead, the relation between them represents antonym interaction where

\footnotetext{
${ }^{11}$ Muslich, Etika, p. 51.

${ }^{12}$ A producer must be responsible if his product harms consumers. If a consumer suffers loss, the producer must replace the product with the new one. K. Bertens, Pengantar., p. 232.

${ }^{13}$ Such as in al-Baqarah (2): 195.

${ }^{14}$ Al-Hasyr (49): 7.

${ }^{15}$ Choirul Fuad Yusuf, "Etika Bisnis Islam: Sebuah Persepektif Lingkungan Global”, Ulumul Qur'an, No. 3, Vol. VIII, 1997, p. 18.

${ }^{16}$ In the contractual relation, both parties can be deemed as good and fair if they understand the substance and the condition of the agreement made. The fair agreement is if no parties intentionally
} 
each party does not exactly know one another except based on an assumption. Moreover, such relation is often mediated by agents and distributors. ${ }^{17}$ This does not mean that there is not right and obligation between them. In fact, their relation represents social interaction which also determines their own right and obligation functioned as the controller. The controller consists of rules of morality embedded in their beliefs and rules of law and their evidence.

These two controllers are mainly attached to the producer. This is because the position of the consumer which is weak and frequently sub-ordinate. In the context of business, the consumer actually pays fee to the producer as it has supplied goods needed professionally. ${ }^{18}$ Therefore, the producer must take the consumer in the best way. This is morally not only ethical demand but is the absolute condition to get success.

The axiom of the unity of Islamic business ethics can be considered in a context where consistency and regularity exist in the relation of the producer and the consumer. The producer will not be greedy as the commodity produced is actually God's gift, ${ }^{19}$ neither will the consumer.

However, though the consumer is called the king, in fact, its position is restricted. It does not have power to freely choice what had been designed. Sometimes, purchasing is done in a pinch where it is not capable of getting its preference. The lack of information on the product and the absence of center for claim cause the disaffection of the consumer. Islam harshly prohibits any forms of jobbery, deception and forgery which tend to harm the consumer. ${ }^{20}$

\footnotetext{
share the false information and that the agreement is not relied on one's coercion.. A. Sonny Keraf, Etika Bisnis Tuntutan dan Relevansinya, (Yogyakarta: Kanisius, 1998), p. 184.

${ }^{17}$ Ibid, p. 185.

${ }^{18}$ Ibid., pp. 186-187.

${ }^{19}$ Al-Kahfi (18): 46.

${ }^{20}$ Choirul Fuad Yusuf, "Etika., p. 18.
} 
According to Ibn Taimiyah, assurance and guarantee for the consumer is part of the responsibility of muhtasib, ${ }^{21}$ an expert (religion and economy) who has the special task to comprehensively monitor economy system. The tasks of muhtasib consist of: fulfilling the availability of supplies in market, monitoring industries including the product standardization, controlling service sectors in order to prevent from deviation of professional tasks such as doctor, pharmacist, and teachers, and controlling trade including monitoring size, weight, and quality of product. ${ }^{22}$

Based on the axiom of free will, a consumer is possible for taking a choice and determining satisfaction on a product consumed. Fundamentally, each person has the character of responsible free will. However, the network structure of producer and its business chain limit consumer's willingness. The producer feels free to implement its plans and strategies to gain a big financial profit.

The awareness of the right of consumer is not totally applied in the business world. In 1962, the US President, John F Kennedy, proposes special massage on protecting the costumer interest to the Congress. This concept comprises four rights of the consumer, that are the right to safety, the right to be informed, the right to choose, and the right to be heard. Furthermore, the consumer also has the right to environment preservation (a guarantee that a commodity is not harmful to the surroundings) and the right to education (the right to be educated to criticize a commodity). In Indonesia, all the rights were ratified in the Act of the Consumer Protection in 1999, including other rights such as the right to have advocacy and protection and the right to get indemnity. ${ }^{23}$

${ }^{21}$ The miltasib institution can be called hisbah This institution, since the Prophet era, has existed though it was commonly applied in the eras afterwards. This institution has some functions, including: First of all, it functions as the system of executing goodness and obligation, done by miltasib and is related to religious and juridical aspects. Secondly, it undertakes practice and techniques of monitoring in detail, including controlling products, trade, administrative claim, quality and standard of products. See, A. A. Islahi, Konseps Ekonom Ibnu Taimyyah terj. Anshari Tayyib, (Surabaya, PT. Bina Ilmu, 1997), p. 238.

${ }^{22}$ Ibid., pp. 240-242.

${ }^{23}$ K Bertens, Pengantar., pp. 228-230. 
The other responsibility of the producer is a guarantee of the quality of products on the one hand and suitable price as well as a guarantee of the true information advertised in the advertising media on the other hand. The quality of production is intended as a guarantee that a product fits the product information, either from information or advertisement. The quality of products is actually not only an ethical demand but also an absolute condition to get success in business. ${ }^{24}$ A consumer who is strictly attached to a certain product is more caused by the evidence of the product quality. One example can be shown here is the package and the label of the product fits the quality of the product. The label may include the religious permission (halal), the date of expiry, and the ingredients.

Price is determined by factors, such as cost product, investment fee, promotion cost, tax fee and logical profit. ${ }^{25} \mathrm{~A}$ fair price in the market economy system is based on capacities played in the market, which is the result of the bargaining process as that practiced by the seller and the buyer in the traditional market. A price can be considered fair if it has been agreed among the parties in a transaction. However, in practice, the market is not the sole factor to determine the fair price.

This condition is influenced by some factors. First of all, the market is never perfect, mainly in terms of capitalist economic system. Secondly, consumers are often on the sub-ordinate position in calculating price and analyzing factors influencing the change of price. Thirdly, the way to determine the price based on the market mechanism causes the high fluctuation of the price. ${ }^{26}$

The high price occurs, mainly in the pricing unfairness, is caused by four factors, which are: 1) deception which occurs due to collusion committed by producer and distributor in the price fixing (conspiratorial price fixing), 2) the ignorance of the consumer and the lack of clear information on the price, 3) the misusage of power, such as price gaming or big price decreasing done by the big party which may effects

\footnotetext{
${ }^{24}$ Ibid., p. 240.

${ }^{25}$ Ibid., p. 241.

${ }^{26}$ Ibid., p. 242.
} 
the small business, 4) manipulation of emotion, which is manipulating one's emotion to gain big financial profit or utilizing the physiological condition of a person who is mourning. ${ }^{27}$

The price unfairness clearly contradicts the axiomatic values of unity, balance, goodness, responsibility and truth. The unfair price triggers the condition of unbalance in the market. The unfair price will not lead to the public benefit, but will cause the emergence of uncertain situation which supports to the despotic actions in the business activities.

One of the concrete ways to share information on a product to consumers is by the advertising media. Advertisement is a manifestation of all marketing aspects which make market as the orientation. Market serves as the target and the source of income which is essential for the sustainability of production. ${ }^{28}$ Advertisement functions to give complete information and standards to society on a promoted product. The completeness and the accuracy of the information shared include the purpose, the composition, the combined elements, the characteristics of the product and other important information. ${ }^{29}$

In this regard, advertisement can be understood as the media of communication of producer and consumer, of seller and buyer which contain messages. Massages in the advertisement have two main functions, informative function and persuasive function. These functions are aimed at attracting the consumer interests. These functions in the advertisement also make ethics emerging. In fact, advertisement is substantially supported by the ideology of consumerism. ${ }^{30}$

${ }^{27}$ Ibid., pp. 243-244.

${ }^{28}$ Muslich, Etika., p. 37.

${ }^{29}$ Ibid., p. 42.

${ }^{30}$ Advertisement is generally understood as having persuasive function. It does not have good reputation either as protector or struggler of rightness. Advertisement frequently contains information which different from the reality to attract consumers' interest in a huge number. Therefore, it is often that advertisement shows a condition of hedonism and materialism. See K Bertens, Pengantar., pp. 263-266. 
Therefore, the basis of business ethic in the advertisement is the principles of unity, responsibility and free will, goodness and truths. In the process of creating and sharing information on a certain product, there must be a belief that there is no single activity that is not controlled by God. Though there are various methods and ways of advertising, the advertiser is responsible socially and transcendentally. The uncontrolled advertisement will negatively effect society even though be profitable in the short term. The value of truth in the advertisement must be preserved in maintaining the true motive of business.

The discussion of business ethics in the advertisement is connected with two points, comprising: 1 . The problem of the true information delivered. 2. The problem of manipulation which often occurs. If, in the advertisement, there is not a lying element so it can be said that such advertisement has truth value. Moreover, in the technology information era, the use of media visual techniques, optic illusion technique can easily manipulate the information on the product and hence consumers are attracted. ${ }^{31}$

The problem of public manipulation through advertisement becomes crucial. Manipulation in terms of attracting people interest is done in such a way so they desire something they do not really need. Due to manipulation, a consumer unconsciously goes with the motivation, not from him/herself but from other parties. In this regard, manipulation is not ethical as it disturbs the autonomy and the freewill of society. ${ }^{32}$

Therefore, to prevent from such impacts, there are two available methods employed, consisting of enhancing awareness of engaged parties in the advertising sector mainly on negative access caused and revitalizing media to control advertisement, such as media watch or corruption watch, which is relied upon the implementation of business ethics.

${ }^{31}$ Ibid., pp. 264-269.

${ }^{32}$ Ibid., pp. 270-273. 
Thus, in the whole series and process of business, from planning, production process, packaging, distributing, advertising, pricing, and quality control are not separated from business principles and business ethics. Business ethics serves as guidance to all parties to make business fertile of ethics values.

\section{Corporate Social Responsibility}

There are three major views on corporate social responsibility. They include: a). A manager of a company seriously focus his attention on the company's interest. By this, he becomes an agent to achieve employees' prosperity. b). A manager has a task to balance main interests of manufacturer. C). A manager is responsible for serving people by undertaking social voluntary activities which is beneficial for public society. ${ }^{33}$

Among the three views, a scholar such as Friedman defines corporate social responsibility as the first and the second one. He argues that corporate social responsibility is aimed at improving good images rather than gaining profit. This opinion is a continuation of a number of views stating that business does not necessarily actualize other motives but economic motive. ${ }^{34}$ If such definition is used to understand corporate social responsibility, we will find unlimited negative impacts, caused by industrial activities, on natural and social environment.

Corporate social responsibility is then a moral responsibility of a company for society, be it for itself, employees, other companies, social environment, or even state. To clearly identify corporate social responsibility, one should differentiate between economic responsibility and social responsibility. The former is commonly indicated by the company's success in gaining profit. This is different from state companies, such the train company. Though, economically, the train company suffers

33 George A. Steiner and John F. Steiner, Business, Goummett and Socidy A Managaial Pespetif, (Singapore: Mc Graw Book Co, 1994), p. 109.

${ }^{34}$ K. Bertens, Pengantar., pp. 292-294. 
a financial loss, its business activity remains working for social responsibility reasons. It can be summed up that social responsibility is out of economic responsibility of a company.

Based on the principle of equality, according to Islam, a manager should organize the salary fee and development of his employess relied upon honesty and justice. ${ }^{35}$ In Islam, Allah obliges a Muslim to share givings for those who have the right, and determine laws based on justice. In the Qur'an chapter 60: 8 on the command of justice and respecting for workers and chapter 4: 149 on the command of respecting privacy and preserving other's secrets, a manager has to be fair in paying the salary for the workers.

The workers must be paid for their salary on time and proportionally. Salary is a right of energy they have poured. Islam condemns any forms of exploitation. The big amount of salary is based on the scope of job so it will not harm both parties (the manager and the employees). ${ }^{36}$

The other ethical action which is linked to the relation of the manager and the employees is the necessity of respecting each other. An employee must keep the private information of the company while the manager does so. To put simply, both parties have an obligation of establishing humane and dialectical relation by avoiding from any tensions. The relation between the two must be based on the value of $i \underline{h} s a \hat{n}$ (goodness) and responsibility, both to Allah and to other people. ${ }^{37}$

This responsibility is a dynamic principle connected with human attitudes in their relation with society and surroundings. A responsibility has dynamic power to defend the quality of balance in the society. In the relation with corporate social responsibility, the axiom of responsibility is manifested in a type of business activity. The responsibility for improving the condition of social environment demands

\footnotetext{
${ }^{35}$ Choirul Fuad Yusuf, “Etika., p. 17.

${ }^{36}$ As stated by the Prophet: "Pay workers' salary before their sweat runs dry." Abu 'Abdillah Muhammad bin Yazid al-Qazwini Ibn Mâjah, Sunan Ibn Mâjah 16 (Semarang: Toha Putra, t.t), II: 84. 37 Choirul Fuad Y usuf, "Etika, p. 17.
} 
manufacturers not only to be depended on their financial profit, but also on other factors. By this responsibility concept, a manufacturer has multilayer characters and will certainly focus on the micro (individual) level and the macro (organizational) level. Both levels should be addressed by a manufacturer mutually. With the axiom of responsibility, the financial business plan will fundamentally shift as justice serves as the main reference.

From the perspective of application, social responsibility can be looked from two sides, positive and negative. In a positive way, a company can perform business activities which do not gain financial profit and is beneficial for social prosperity. In a negative way, a company is able to defend itself not to perform activities which are basically beneficial for the company owner but harmful to society.

In fact, with regard to the industrial history, there are a number of big companies harvest good image not from business activities but from philanthropic actions. ${ }^{38}$ Such philanthropy can strengthen the image of a company in the society. This proves that the good work quality of a company is not only indicated by the business activity itself but by social works contributed to the society as the implementation of corporate social responsibility on the one hand and as the way to strengthen the good image on the other hand. Thus, social works in the general meaning do not necessarily contradict the long-term economic motives, instead they support such motives.

Therefore, business institutions are claimed to be involved in developing their social responsibility. Because the business institution has strategic position in developing society, it needs instruments to increase the levels of sensitivity and social responsibility. Accelerating and strengthening such levels will be able to make balance of people's welfare. There two approaches can be applied which comprise:

38 The real example is Carnegie which gives big donation to educational institutions and 28.000 libraries. Besides that, Bill Gate is one who gives his donation to develop technology information in the social and educational institutions. See K Bertens, Pengantar., pp. 299-302. 
First of all, explicit approach can be employed by developing ethics code, strengthening ethical support, improving the quality of selection process and training on ethics as well as maintaining reward system. ${ }^{39}$ Secondly, implicit approach can be implemented in some actions, consisting of: (1) Changing the structure of culture by disseminating values and norms in the society. Islam as the religion of values and guidance of all aspects of life will easily serve as the agent of change. (2) Developing the informal communication channel in order to be acquainted with issues related to immorality. ${ }^{40}$ As a result, the efforts of maintaining and developing Islamic business ethics in the business activities in the global atmosphere will be easily implemented.

\section{Conclusion}

In Islam, business and ethics are not separated entities, but are unified in an integrated structure. In such integration, Islam provides a paradigm structure of business ethics, which is business established on the principles of unity, free choice, responsibility, justice, truth, and honesty.

The relation between producer (employer) and consumers, including the quality and the safety of products and price fairness, is sustainable business which is impossible to be alienated from ethics values. The application of Islamic business ethics is not only related to the responsibility of the business owner to God, but is also connected with the existence of employer who should remain to exist in the business world.

Corporate social responsibly for workers also requires Islamic business ethics as the ethical foundation to be agreed and to attain the harmonic relationship between the two. The employer also has big obligation by paying for salary based upon the quality of the work. Furthermore, a manager of a company has to respect for the faith

\footnotetext{
${ }^{39}$ Choirul Fuad Yusuf, "Etika., p. 21

${ }^{40}$ Ibid.
} 
adhered by the workers. To create harmonious relationship, the employees have big responsibilities for working well and being responsible. Corporate social responsibility is also connected with the real condition of society. A company also has to perform social activities for improving the prosperity of people and preserving the balance of the surrounding environment.

\section{BIBLIOGRAPHY}

A. Nugroho, Alois. 1997. "Lima Pandangan Tentang Relevansi Etika Bagi Dunia Bisnis: Sebuah Usaha Pemetaan Awal”, Driyarkara, Tahun XXIII. No. 3.

'Abdillah Muhammad bin Yazid al-Qazwini Ibn Majah, Abu. Sunan Ibn Majah " 16 Semarang: Toha Putera.

Bertens, K. 2000. Pengantar Etika Bisnis, Yogyakarta: Kanisius.

Buchari, Alma. 1997. Pengantar Bisnis, Bandung: CV Alfabeta.

Dani Saliswijaya, Aan. 2004. Himpunan Peraturan tentang Class Action, Jakarta: Gramedia Pustaka Utama.

De George, Ricard T. 1986.Business Ethics, New Jersey Hall: Englewood Cliffs.

Fuad Yusuf, Choirul. 1997. "Etika Bisnis Islam: Sebuah Persepektif Lingkungan Global”, Ulumul Qur'an, No. 3, Vol. VIII.

George A, Steiner and John F. Steiner. 1994. Business, Government and Society A Managerial Perspectif, Singapure: Mc Graw Book Co.

Islahi, A. A. 1997. Konsepsi Ekonomi Ibnu Taimiyyah, terj. Anshari Tayyib, Surabaya, PT. Bina Ilmu.

Keraf, Sonny. 1998. Etika Bisnis Tuntutan dan Relevansinya, Yogyakarta: Kanisius. $05-06$

Mei-Juni 1997. "Bisakah Bisnis Berjalan tanpa Moralitas”, Basis, No.

Muslich. 1998. Etika Bisnis Pendekatan Subtantif dan Fungsional, (Yogyakarta: Ekonomia Kampus Fakultas Ekonomi UII Yogyakarta.

Nidal S Sabri dan M. Hisyam Jabir. 1997. "Etika Bisnis dan Akutansi”, dalam Sofyan Safri Harahap, Akuntansi Islam, Jakarta: Bumi Aksara.

Sudarmadji, Hari. 2000. "Masalah-masalah Etika Bisnis", Hand out pada seminar Kajian Kritis Strategi Pemulihan Ekonomi Indonesia, dalam rangka 45 tahun FE UGM, 15 September. 